\title{
DESAIN APLIKASI UNTUK MENGHITUNG KEBUTUHAN KALORI HARIAN DENGAN ALGORITMA MIFFLIN - ST JEOR DAN HARRIS - BENEDICT BERBASIS ANDROID
}

\author{
Pahrizal $^{1}$, Pere Arizona ${ }^{2}$ \\ ${ }^{1}$ Fakultas Teknik, Universitas Muhammadiyah Bengkulu \\ Jl. Bali PO BOX 118. Telp (0736) 227665, Fax (0736) 26161, Bengkulu 38119 \\ fahrizal1202@gmail.com \\ ${ }^{2}$ Fakultas Teknik, Universitas Muhammadiyah Bengkulu \\ Jl. Bali PO BOX 118. Telp (0736) 227665, Fax (0736) 26161, Bengkulu 38119 \\ perearizona1234@gmail.com
}

\begin{abstract}
Calorie is a unit of measurement to express the value of energy. In nutritional science, calories are energy derived from food and drink and energy use in physical activity. Our body needs calories to generate energy. Calories plays an important role in our life, without energy, the body cells can die, the organ system in our body can stop working, and we can not do our daily activities well. From the problem the writer will discuss about how to count food calories by using Mifflin - St Jeor and Harris - Benedict algorithm based on android. The benefit of the research is to help people to count calories need by human body in one day and to help people who are in diet program. This research held in the writer's residence because it is an individual research. Mifflin - ST Jeor and Haris Benedict is a method used to used to estimate individual basal level (AMB) and physical activity. AMB is influenced by age, gender, weight and height.
\end{abstract}

Keyword:Applications, Calories, Mifflin-ST Jeor And Haris-Benedict

Abstrak - Kalori adalah merupakan satuan ukur untuk menyatakan nilai energi. Dalam ilmu gizi, kalori adalah merupakan energi yang diperoleh dari makanan dan minuman serta penggunaan energi dalam aktivitas fisik. Tubuh kita memerlukan kalori untuk mengahsilkan energi. Energi sangat berperan penting dalam kehidupan, tanpa energi, sel-sel tubuh bisa mati, sistem-sistem organ dalam tubuh bisa berhenti, serta tidak dapat melakukan aktivitas sehari-hari. Dari permasalahan tersebut maka penulis akan membahas bagaimana merancang aplikasi untuk menghitung kalori makanan dengan algoritma Mifflin St Jeor dan Harris - Benedict berbasis android. Sehingga manfaat dari penelitian ini adalah dapat Membantu mempermudah dalam menghitung kalori yang di butuhkan tubuh dalam satu hari dan Membantu dalam program diet karena dapat menentukan kalori sesuai program diet. penelitian ini dilaksanakan di tempat tinggal peneliti karena bersifat penelitian mandiri. Mifflin-ST Jeor Dan HarisBenedict adalah Metode yang digunakan untuk memperkirakan individu tingkat basal metabolisme (AMB) dan aktifitas fisik. AMB dipengaruhi olehUmur,Gender,Berat Badandan Tinggi Badan Kata kunci: Aplikasi, kalori, Mifflin-ST Jeor Dan Haris-Benedic

\section{Pendahuluan}

Kesehatan adalah bagian terpenting dalam hidup kita. Namun masih jarang orang yang peduli dengan kesehatannya sendiri. Salah satu cara menjaga kesehatan adalah dengan mengatur pola makan. Mengatur pola makan memang paling sering diabaikan oleh banyak orang. Padahal makanan yang dimakan bisa menjadi pintu masuk bagi berbagai penyakit. Melakukan pola makan yang salah dapat menyebabkan masalah kesehatan seperti kegemukan, obesitas, diabete, serangan jantung, hipertensi dan stroke, itu hanya beberapa contoh yang bisa timbul akibat kesalahan pola makan.

Dan tentunya ketika pola makan tidak teratur, ketidak seimbangan berat badan akan menjadi masalah bagi sebagian besan orang. Hal ini dikarenakan rendahnya kesadaran mereka akan makanan sehat, banyak orang jaman sekarang ini yang lebih memilih fast food disbanding dengan makanan sehat, oleh karena itu banyak diantara mereka yang akhirnya mengalami kegemukan atau obesitas dan berbagai penyakit lainnya. (Deddy Pamudji, 2011)

Yang menjadi masalah dalam mengatur pola makan tersebut adalah tidak semua orang tahu mengenai jumlah kalori yang dibutuhkan tubuh mereka untuk melakukan aktifitas seharihari dan jumlah kalori yang terkandung di dalam makanan yang mereka konsumsi. Menghitung jumlah kalori memang tidak mudah, setidaknya setiap orang harus mencari informasi kandungan kalori makanan melalui info data dan gizi pada makanan. Hal ini mungkin yang membuat orang enggan untuk memperhatikan kandungan kalori yang mereka makan. Apalagi makanan yang mengandung kalori berlebih biasanya memiliki rasa yang 
lebih enak. Namun, tetap harus bijak dalam memilih makanan yang akan dikonsumsi.(Irma Eka Ayu, 2015)

Dari permasalahan diatas penulis mencoba membuat aplikasi yang bisa membantu dalam hal menghitung kebutuhan kalori harian, dan mengetahui jumlah kandungan kalori yang terdapat pada makanan, yang diharapkan dapat membantu masyarakat khususnya bagi penderita obesitas dalam mengatur pola makan menjadi lebih baik. Aplikasi yang di buat berbasis android karena smartphone android merupakan device yang paling populer saat ini.

\section{Metode Penelitian}

\subsection{Model Pengembangan Sistem}

Model Incremental process model merupakan metodologi yang mengkombinasi linier dan iteratif aliran proses dalam pengembangan perangkat lunak. Tujuan utama kombinasi dan iterativ ini adalah mengurangi resiko kegagalan proyek dengan cara memecah pekerjaan menjadi bagian-bagian yang lebih kecil selama pengembangan. Prinsip dasar dalam incremental process model antara lain adalah sebagai berikut:

a. Serangkaian waterfall mini yang harus diselesaikan sebelum melakukan increment berikutnya

b. Semua requirement dilakukan sebelum dilakukan evolusioner

c. Fase-fase dalam setiap increment dilakukan seperti waterfall sehingga diperoleh perangkat lunak yang diinginkan dengan mengikuti fase iteratif seperti pendekatan prototyping.

Tahapan model pengembangan Incremental :

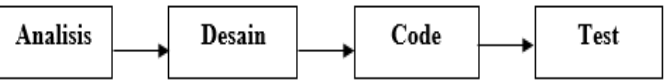

Gambar 3.1 Tahapan Model Incremental
1. Flowchart

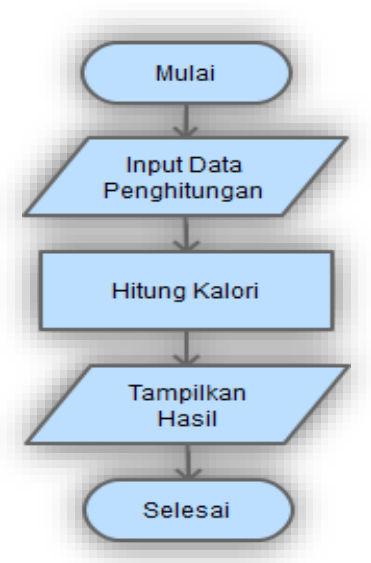

Gambar 3.2 Flowchart Aplikasi Kalori Harian

2. Struktur Menu

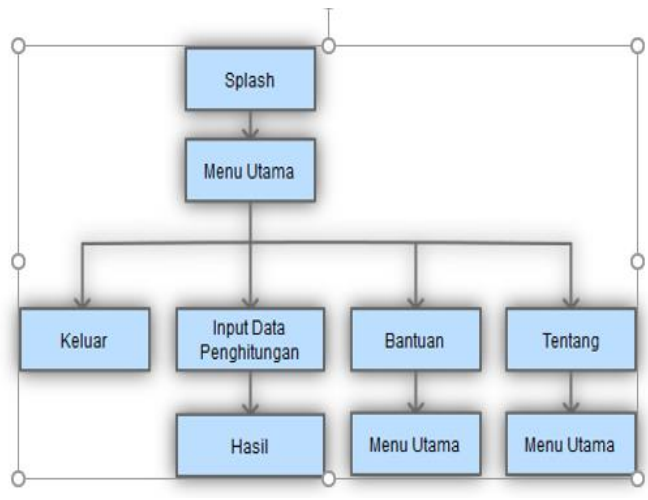

Gambar 3.3 Struktur Menu

3. Desain Rancangan

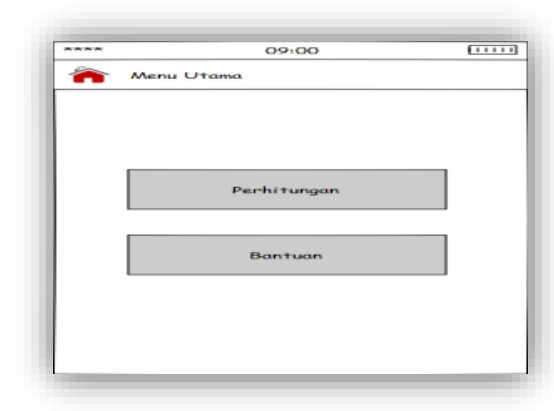

Gambar 3.4 Tampilan Menu Utama

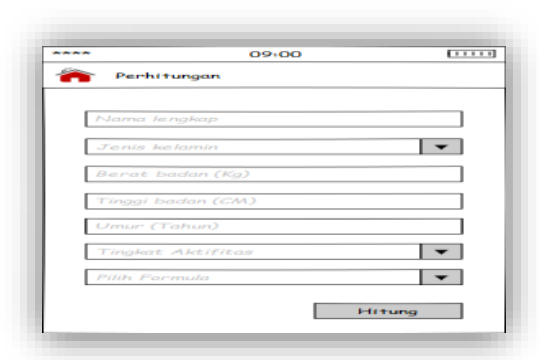




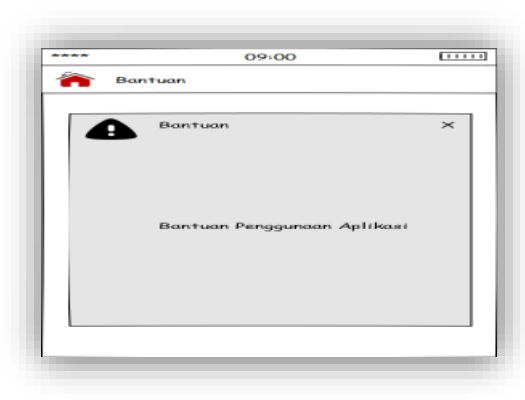

Gambar 3.6 Tampilan Menu Bantuan

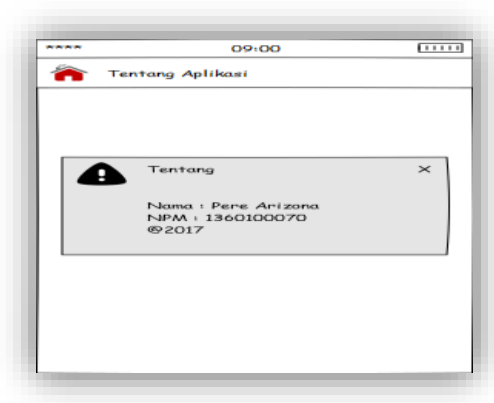

Gambar 3.7 Tampilan Menu Tentang

\section{Hasil dan Diskusi}

\subsection{Hasil}

3.1.1 Splash Screen Aplikasi

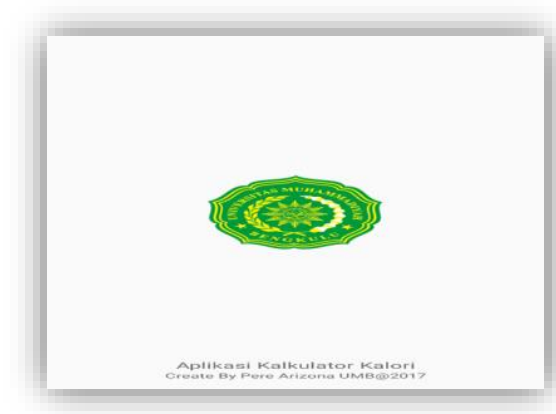

Gambar 4.1 Splash Screen Aplikasi

Ini adalah tampilan Splash Screen ketika pertama kali kita menjalankan Aplikasi

\subsubsection{Menu Utama}

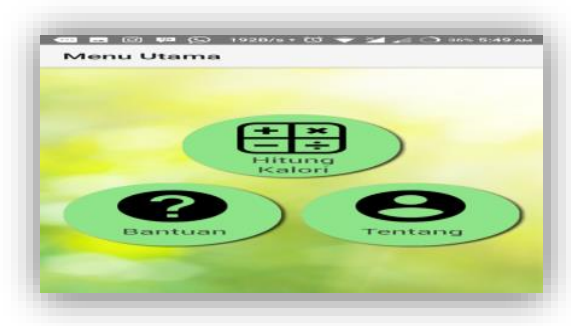

Gambar 4.2 Menu Utama

Ini adalah tampilan menu utama setelah tampilan splash screen, di dalam menu ini terdapat menu Hitung Kalori,Bantuan dan tentang.

\subsubsection{Menu Perhitungan Kalori}

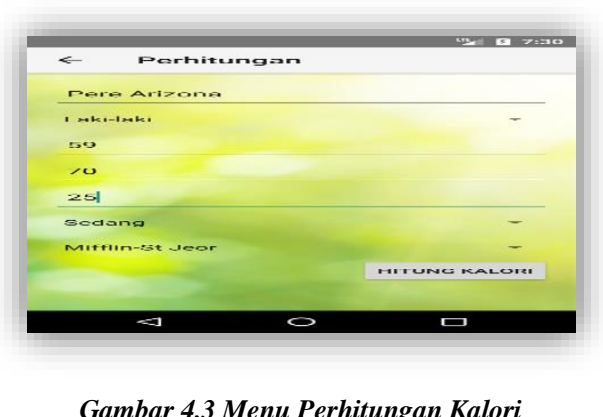

Pada menu ini pengguna dapat Menghitung Kebutuhan Kalori yang dibutuhkan setiap harinya dengan menginput Nama, jenis kelamin, berat badan, tinggi badan, umur, Tingkat aktifitas dan memilih Formula yang diterapkan adapun formula yang diterapkan ialah formula Mifflin St-Jeor dan Harris Benedict.

\subsubsection{Menu Hasil Perhitungan}

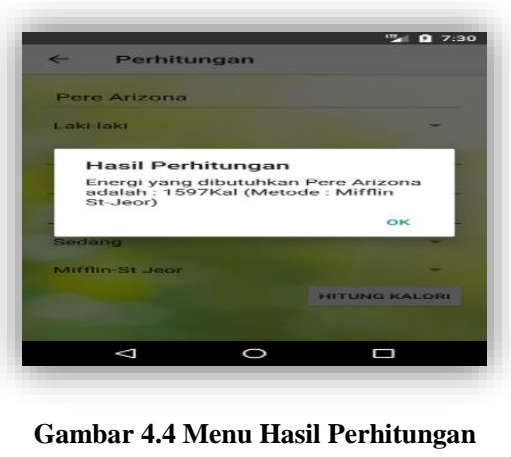

Ini adalah menu tampilan hasil setelah pengguna melakukan perhitugan pada menu perhitungan kalori, di dalam menu ini pengguna dapat melihat hasil kebutuhan kalori harian yang dibutuhkan.

\subsubsection{Menu Bantuan}

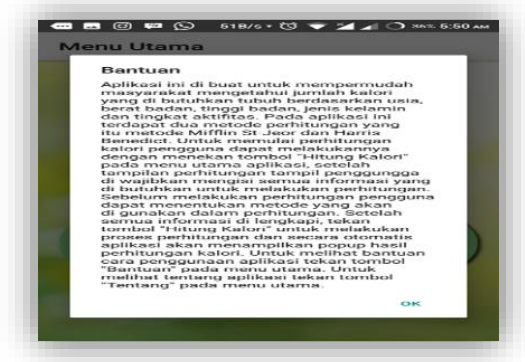

Gambar 4.5 Menu Bantuan

Menu bantuan Merupakan tampilan menu yang menampilkan keterangan tentang aplikasi dan cara penggunaan aplikasi. 


\subsubsection{Menu Tentang}

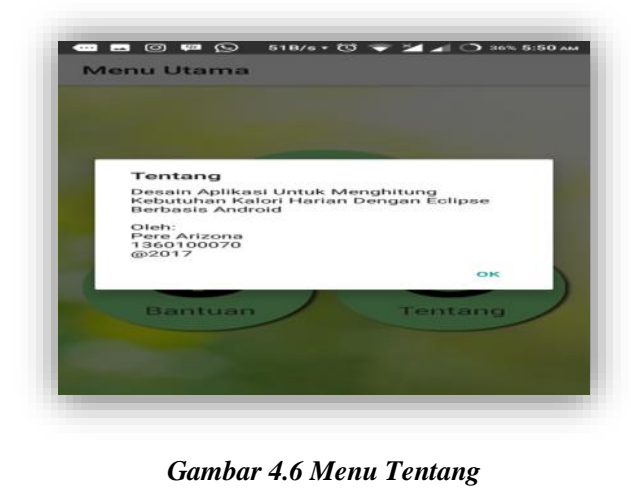

Menu tentang merupakan tampilan tentang keterangan aplikasi dan pembuat aplikasi.

\subsection{Pembahasan}

\subsubsection{Formula Mifflin St-Jor}

Rumus persamaan ala Mifflin StJeoryang digunakan adalah $(10 \mathrm{x}$ berat badan satuan kilogram $)+(6.25 \mathrm{x}$ tinggi badan satuan centimeters $)$ - ( $5 \mathrm{x}$ usia satuan tahun $)$ - 161. Jika bobot tubuh anda 135 pon, usia 25 tahun, tinggi 5 kaki 6 inci, maka kalkulasi BMR sebagai berikut: $(10 \times 61)+(6.25 \mathrm{x}$ $168)-(5 \times 25)-161=1,374$ kalori.

\subsubsection{Formula Harris Benedict}

Metode yang digunakan untuk memperkirakan individu tingkat basal metabolisme (AMB) dan aktifitas fisik. AMB dipengaruhi olehUmur,Gender,Berat Badandan Tinggi Badan. Cara menentukan AMB yaitu :

$$
\begin{aligned}
& \text { 1. Laki-Laki : } 66+(13,7 \times \mathrm{BB})+(5 \times \mathrm{TB}) \\
& \text { - }(6,8 \times \mathrm{U}) \\
& \text { 2. Perempuan : } 665+(9,6 \times \mathrm{BB})+(1,8 \times \mathrm{TB}) \\
& \text { - }(4,7 \times \mathrm{U})
\end{aligned}
$$

\section{Kesimpulan}

\subsection{Kesimpulan}

Dari hasil analisa, perancangan, pengujian dan implementasi program yang telah dilakukan terhadap aplikasi menghitung kalori makanan dengan algoritma Mifflin-St Jeor dan HarrisBenedict berbasis android, dapat disimpulkan sebagai berikut :

1. Pembuatan aplikasi penghitung Kalori ini berguna untuk membantu pengguna dalam mengetahui kebutuhan kalori harian merekasesuai dengan metode Mifflin-St Jeor dan Harris-Benedict. Aplikasi ini juga dapat menghitung jumlah kalori harian sesuai dengan data yang di-input oleh pengguna.

2. Program ini juga bisa membantu pengguna dalam mengetahui golongan berat badan mereka berdasarkan data yang telah diinput seperti tinggi dan berat badan pengguna sesuai dengan metode Mifflin-St Jeor dan HarrisBenedict.

\subsection{Saran}

Penelitian yang dilakukan tentunya tidak terlepas dari kekurangan dan kelemahan. Oleh karena itu, untuk kebaikan pengembangan sistem lebih lanjut, maka penulis menyarankan beberapa hal di antaranya :

1. Dikarenakan ilmu pengetahuan terus berkembang dan ditemukannya hal-hal baru maka basis pengetahuan dan basis aturan sistem ini perlu di update atau ditambah, sehingga data-data yang ada menjadi lebih lengkap dan kompleks.

2. Interface (tampilan) sistem yang dibangun masih tampak sederhana, sehingga dapat dikembangkan lebih menarik dengan dilengkapi multimedia (suara dan gambar) maupun animasi.

\section{Referensi}

[1] Budi, Wahyu Ningsih, "Definisi Perancangan menurut bin Ladjamudin",

http://elib.unikom.ac.id/files/disk1/526/jbptunikomppgdl-rdhendraca-26274-6-unikom r-i.pdf, 2016.

[2] Dengen, "pengertian perancangan", Jakarta, 2009.

[3] Irma Eka Ayu, "Pengembangan Aplikasi Untuk Kebutuhan Jumlah Kalori”, Surakarta, 2015.

[4] Ichwan, "Definisi Android", Jakarta, 2011.

[5] Pamudji, Deddy., "Aplikasi Penghitung Kalori Makanan Berbasis Android 2.1", Jakarta ,2011.

[6] Rosa dan shalahuddin, "pengertian dari perangkat lunak", Jakarta, 2011.

[7] Raharjo, Budi., Imam Heryanto \& Arif Haryono. MudahBelajar Java. Bandung: Informatika. 2009.

[8] Safaat, Nazruddin H.Pemrograman Aplikasi MobileSmartphone dan Tablet PCBerbasis Android. Bandung: Informatika. 2011. 